\title{
Iron, Nitrogen-Doped Carbon Aerogels for Fluorescent and Electrochemical Dual-Mode Detection of Glucose
}

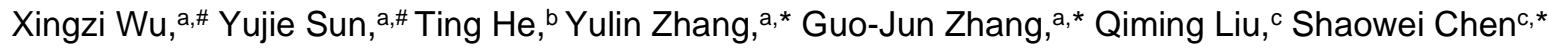 \\ a School of Laboratory Medicine, Hubei University of Chinese Medicine, 16 Huangjia Lake West Road, \\ Wuhan, Hubei 430065, People's Republic of China \\ b School of Chemistry and Chemical Engineering, Central South University, Changsha, Hunan 410083, \\ People's Republic of China \\ c Department of Chemistry and Biochemistry, University of California, 1156 High Street, Santa Cruz, \\ California 95064, United States
}

*E-mail: zhangyulin2001@163.com (Y.L.Z.), zhanggi@hbtcm.edu.cn (G.J.Z.), shaowei@ucsc.edu (S.W.C.)

\# These authors contributed equally to the work. 


\section{List of contents}

\begin{tabular}{|c|c|}
\hline Figure S1 & SEM image of NCAG/Fe. \\
\hline Figure S2 & $\begin{array}{l}\text { Nitrogen adsorption-desorption isotherm of NCAG/Fe. Inset is the corresponding pore } \\
\text { size distribution. }\end{array}$ \\
\hline Figure S3 & High-resolution XPS scan of the $\mathrm{O}$ 1s electrons of NCAG/Fe. \\
\hline Figure S4 & Fe K-space EXAFS profile of NCAG/Fe and the corresponding fit \\
\hline Figure S5 & $\begin{array}{l}\text { Fluorescence spectra of } \mathrm{NCAG} / \mathrm{Fe}+\mathrm{H}_{2} \mathrm{O}_{2}, \mathrm{NCAG} / \mathrm{Fe}+\mathrm{OPD}, \mathrm{NCAG} / \mathrm{Fe}+\mathrm{H}_{2} \mathrm{O}_{2}+ \\
\mathrm{OPD}, \mathrm{NCAG} / \mathrm{Fe}, \mathrm{OPD}, \mathrm{OPD}+\mathrm{H}_{2} \mathrm{O}_{2} \text { and } \mathrm{NCAG}+\mathrm{H}_{2} \mathrm{O}_{2}+\mathrm{OPD} \text { at the excitation of } 414 \\
\mathrm{~nm} \text {. }\end{array}$ \\
\hline Figure S6 & $\begin{array}{l}\text { Effect of NCAG/Fe concentration, OPD concentration, response time and temperature } \\
\text { on the detection of } \mathrm{H}_{2} \mathrm{O}_{2}\end{array}$ \\
\hline Figure S7 & Effect of the $\mathrm{pH}$ value on the fluorescence response efficiency $\left(\mathrm{F} / \mathrm{F}_{0}\right)$ to $\mathrm{H}_{2} \mathrm{O}_{2}$ detection. \\
\hline Figure S8 & Linear range (calibration curve) for the detection of $\mathrm{H}_{2} \mathrm{O}_{2}$. \\
\hline Figure S9 & $\begin{array}{l}\text { Dependence of the fluorescence response efficiency on GOx concentration and } \\
\text { incubation time. }\end{array}$ \\
\hline Figure S10 & Chronoamperometric profiles of different modified electrodes. \\
\hline Figure S11 & $\begin{array}{l}\text { Amperometric curves of } \mathrm{NCAG} / \mathrm{Fe} \text { in } \mathrm{PBS} \text { or } \mathrm{NaOH} \text { solution at different concentrations } \\
\text { or different applied potentials. }\end{array}$ \\
\hline Figure S12 & $\begin{array}{l}\text { Current increments observed in amperometric measurements with five } \\
\text { NCAG/Fe-modified electrodes. }\end{array}$ \\
\hline Table S1 & Elemental composition of NCAG/Fe from XPS measurements. \\
\hline Table S2 & Contents (at\%) of different $\mathrm{N}$ species from XPS measurements. \\
\hline Table S3 & Fitting results of the EXAFS data for NCAG/Fe. \\
\hline Table S4 & Comparison of the kinetic parameters of NCAG/Fe and HRP. \\
\hline Table S5 & $\begin{array}{l}\text { Comparison of glucose sensing performance with relevant results reported recently in } \\
\text { the literature. }\end{array}$ \\
\hline
\end{tabular}




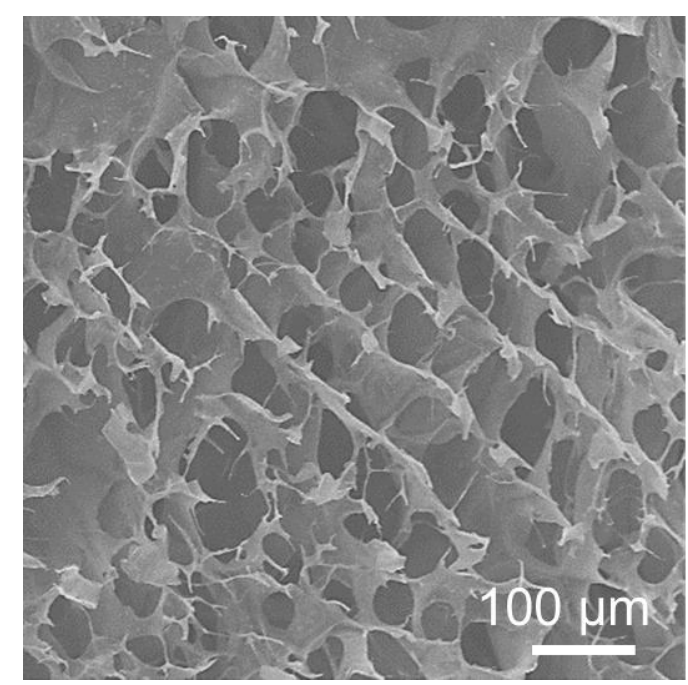

Figure S1. SEM image of NCAG/Fe.

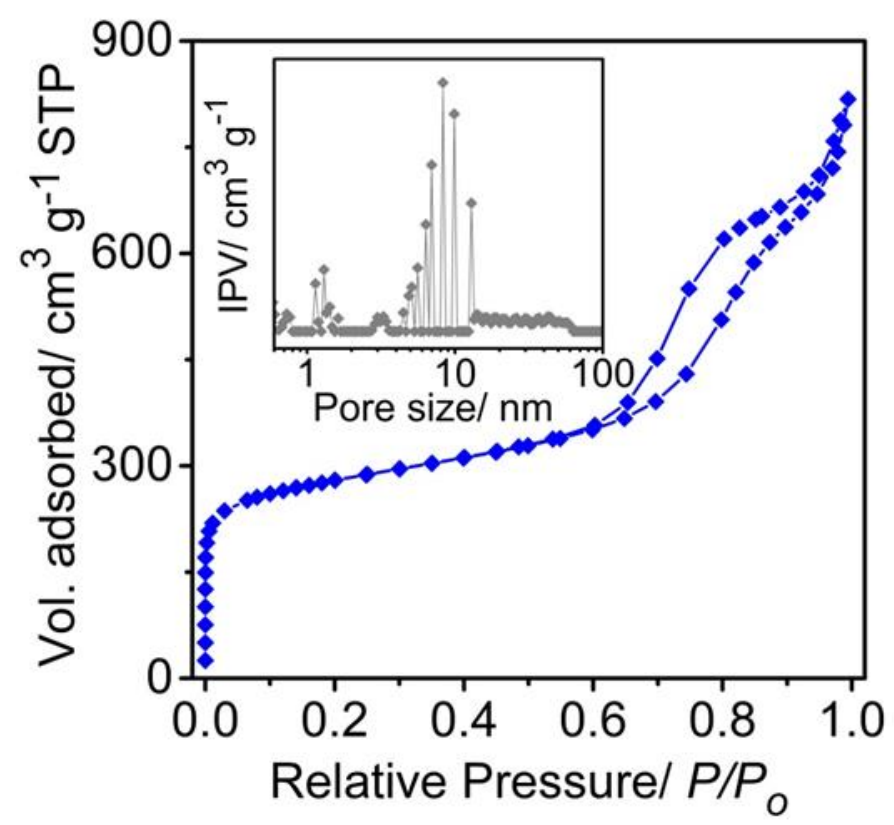

Figure S2. Nitrogen adsorption-desorption isotherm of NCAG/Fe. Inset is the corresponding pore size distribution. 


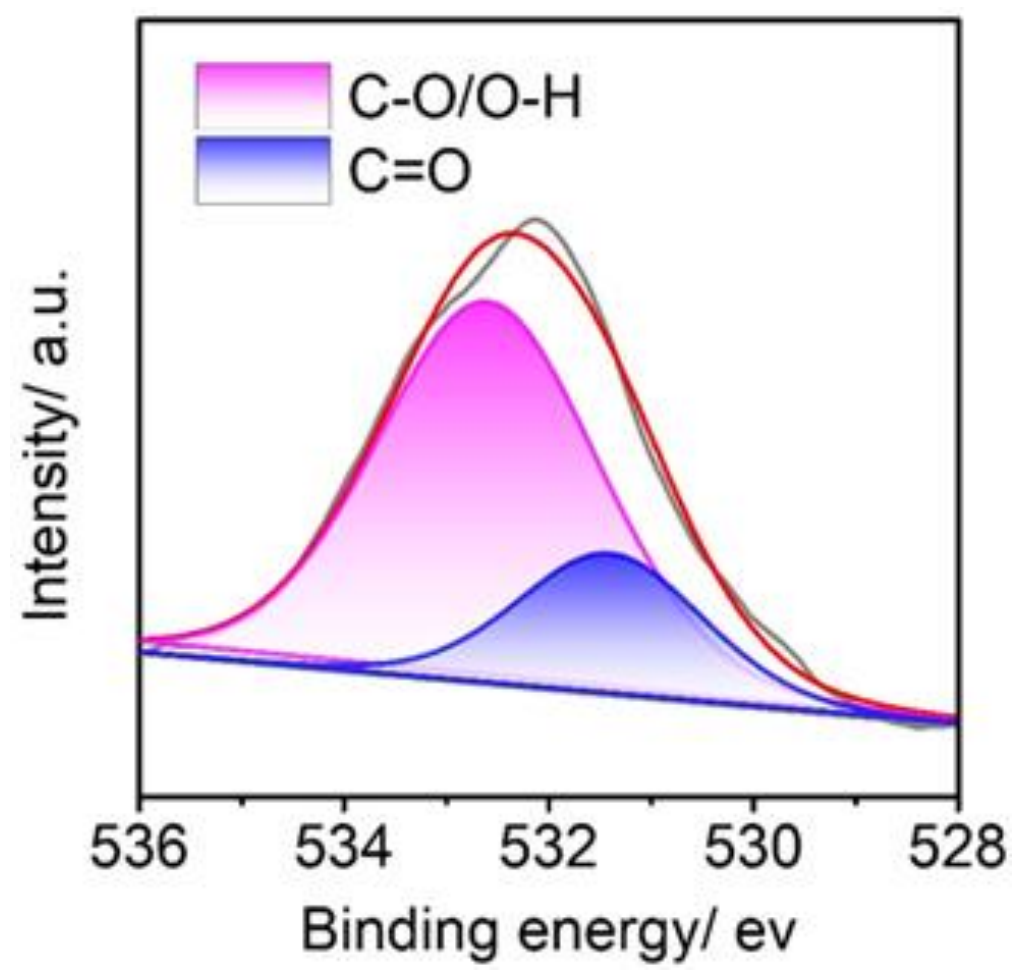

Figure S3. High-resolution XPS scan of the O 1s electrons of NCAG/Fe.

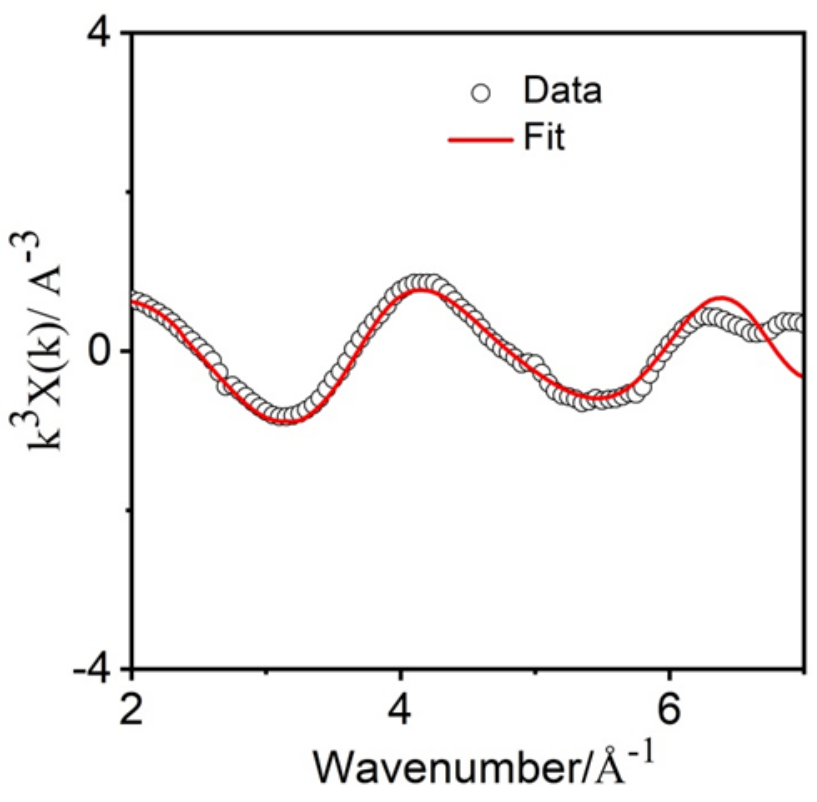

Figure S4. Fe K-space EXAFS profile of NCAG/Fe and the corresponding fit. 

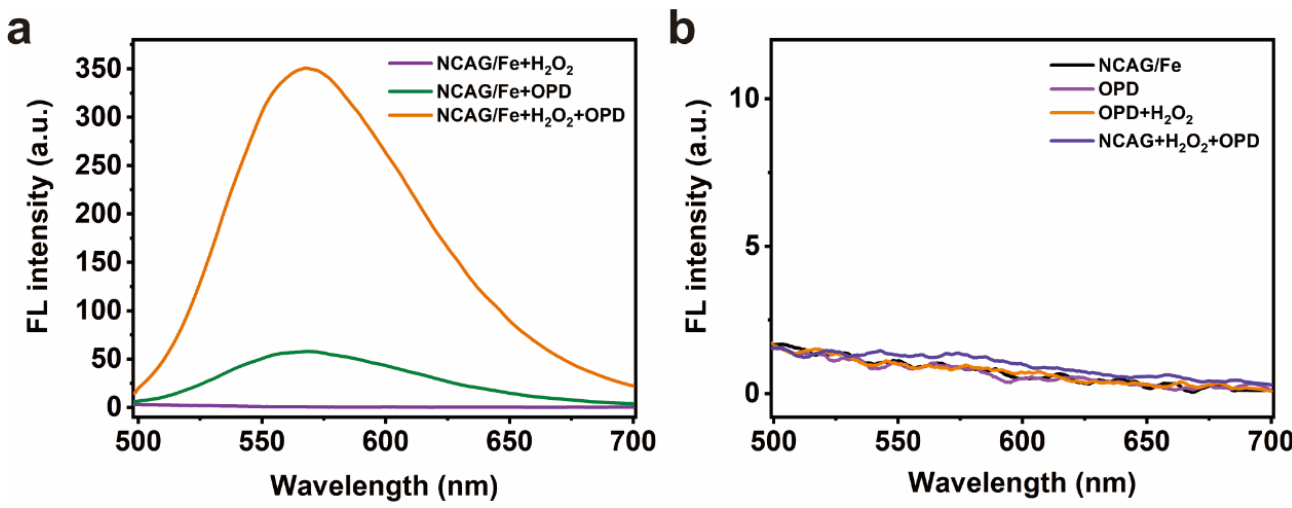

Figure S5. (a) Fluorescence spectra of $\mathrm{NCAG} / \mathrm{Fe}+\mathrm{H}_{2} \mathrm{O}_{2}, \mathrm{NCAG} / \mathrm{Fe}+\mathrm{OPD}$ and $\mathrm{NCAG} / \mathrm{Fe}+\mathrm{H}_{2} \mathrm{O}_{2}+\mathrm{OPD}$ at the excitation of $414 \mathrm{~nm}$. The concentrations are $20 \mu \mathrm{g} / \mathrm{mL}$ for OPD, $1 \mathrm{mM}$ for $\mathrm{H}_{2} \mathrm{O}_{2}$, and $10 \mu \mathrm{g} / \mathrm{mL}$ for NCAG/Fe in a phosphate buffer solution ( $\mathrm{pH}$ 7.4). (b) Fluorescence spectra of NCAG/Fe, OPD, $\mathrm{OPD}+\mathrm{H}_{2} \mathrm{O}_{2}$ and $\mathrm{NCAG}+\mathrm{H}_{2} \mathrm{O}_{2}+\mathrm{OPD}$ at the excitation of $414 \mathrm{~nm}$. The concentrations of NCAG/Fe, $\mathrm{NCAG}, \mathrm{OPD}$, and $\mathrm{H}_{2} \mathrm{O}_{2}$ were $10 \mu \mathrm{g} / \mathrm{mL}, 10 \mu \mathrm{g} / \mathrm{mL}, 20 \mu \mathrm{g} / \mathrm{mL}$ and $1 \mathrm{mM}$, respectively. Fluorescence tests were conducted using a Hitachi F-4600 fluorescence spectrophotometer (Hitachi Co. Ltd., Japan). Fluorescence spectrum measurement conditions: Xenon lamp excitation, excitation and emission slit width are $5.0 \mathrm{~nm}$, voltage is set at $700 \mathrm{~V}$, response time is $0.1 \mathrm{~s}$, excitation wavelength is $414 \mathrm{~nm}$, emission wavelength scanning range is $490 \sim 700 \mathrm{~nm}$.
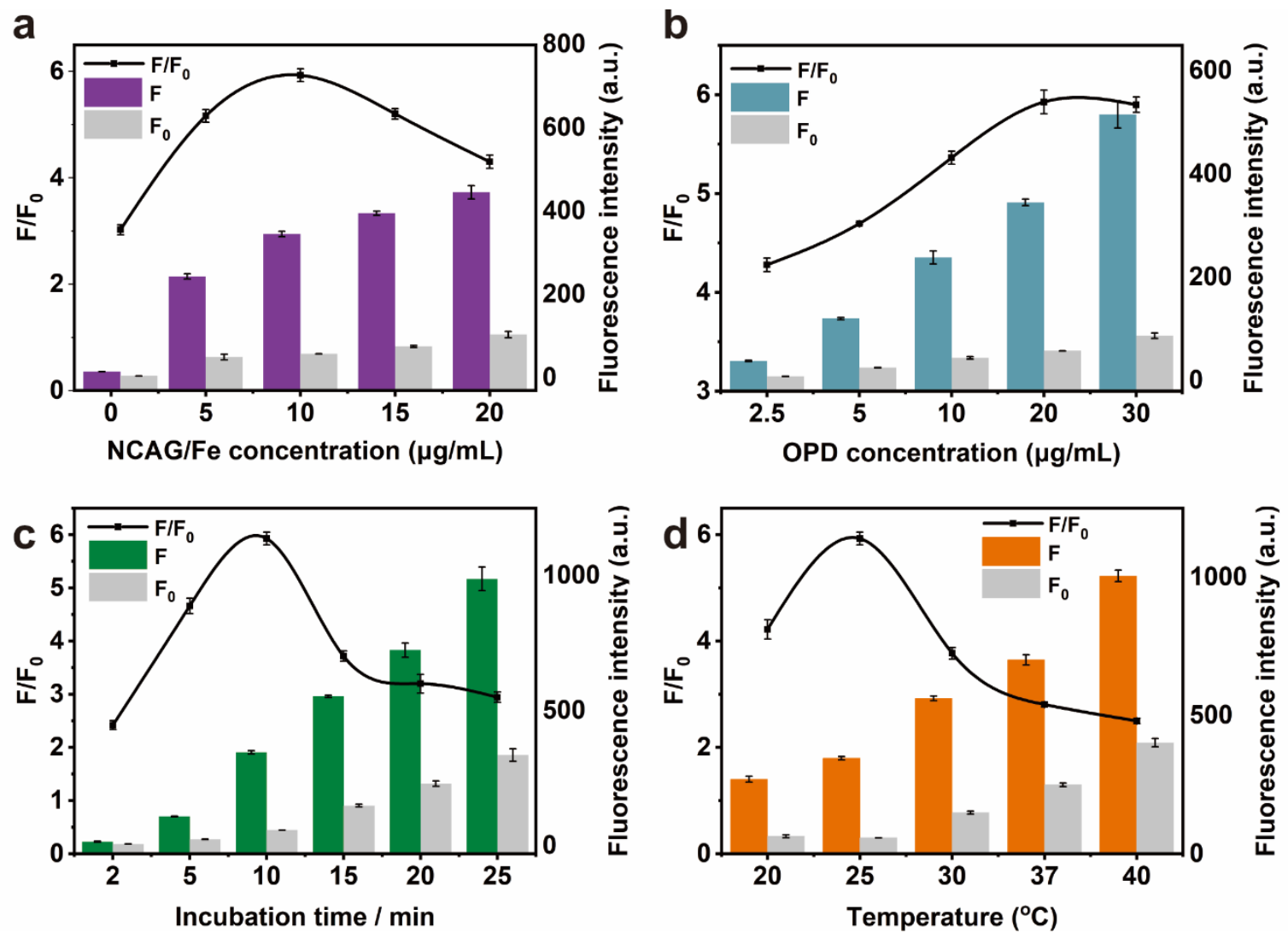

Figure S6. (a) Effect of NCAG/Fe concentration on the fluorescence response efficiency $\left(\mathrm{F} / \mathrm{F}_{0}\right)$ to $\mathrm{H}_{2} \mathrm{O}_{2}$ detection. (b) Fluorescence response efficiency $\left(F / F_{0}\right)$ responses to the different concentration of OPD. (c) Time response on the fluorescence response efficiency $\left(F / F_{0}\right)$ to $\mathrm{H}_{2} \mathrm{O}_{2}$, (d) Effect of temperature on the detection of $\mathrm{H}_{2} \mathrm{O}_{2}$. 


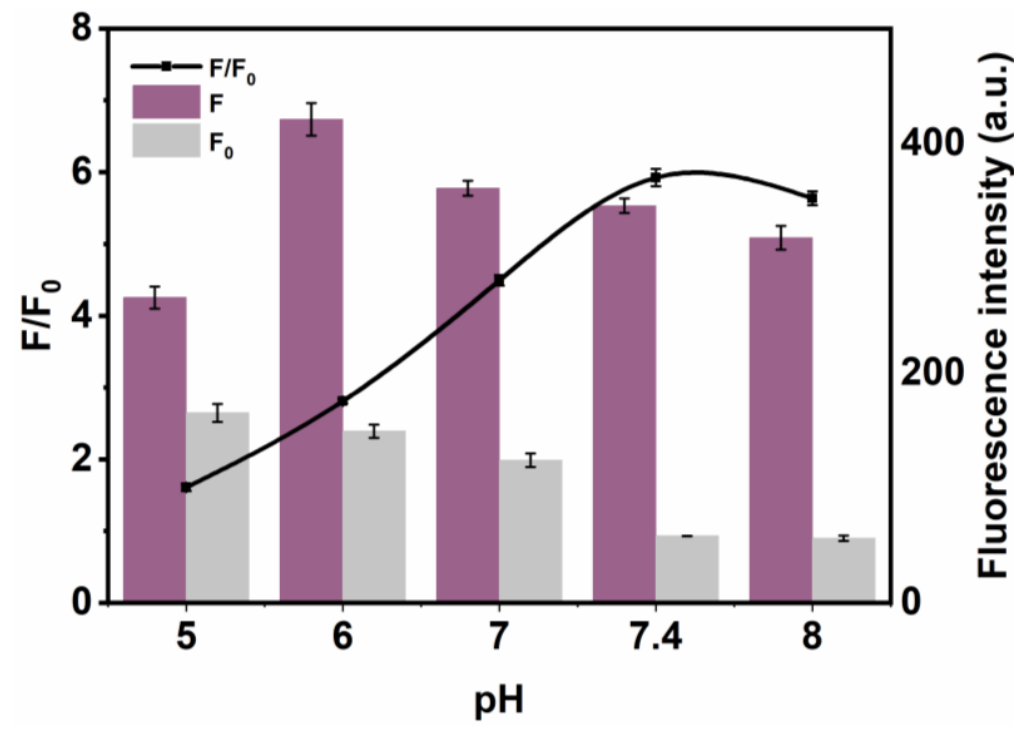

Figure S7. Effect of the $\mathrm{pH}$ value on the fluorescence response efficiency $\left(\mathrm{F} / \mathrm{F}_{0}\right)$ to $\mathrm{H}_{2} \mathrm{O}_{2}$ detection.

a

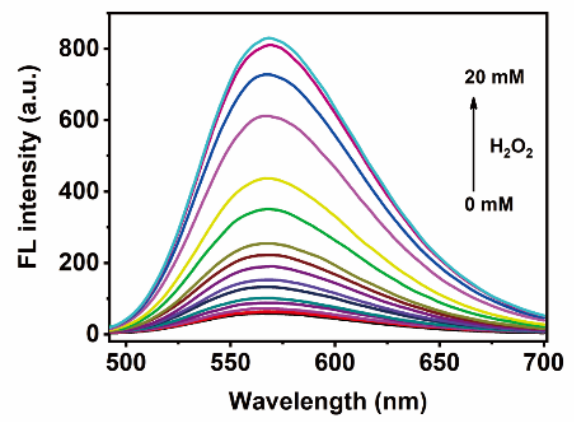

b

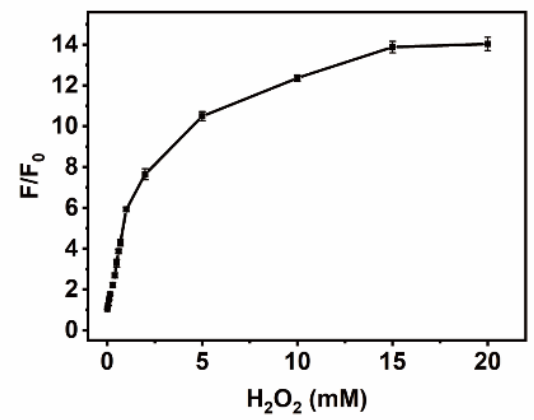

C

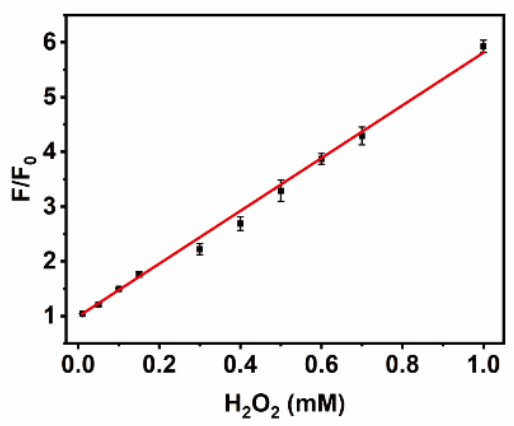

Figure S8. (a) For the quantitative detection of $\mathrm{H}_{2} \mathrm{O}_{2}, 50 \mu \mathrm{L}$ of a $\mathrm{H}_{2} \mathrm{O}_{2}$ aqueous solution at different concentrations was added into $950 \mu \mathrm{L}$ of a phosphate buffer (pH 7.4) containing $10 \mu \mathrm{g} / \mathrm{mL}$ of NCAG/Fe and $20 \mu \mathrm{g} / \mathrm{mL}$ of OPD. The resulted solution was incubated for $10 \mathrm{~min}$ at $25{ }^{\circ} \mathrm{C}$ and fluorescence spectra were acquired under $414 \mathrm{~nm}$ excitation. (b) Fluorescence response efficiency ( $\left.F / F_{0}\right)$ versus $\mathrm{H}_{2} \mathrm{O}_{2}$ concentration. (c) Linear range (calibration curve) for the detection of $\mathrm{H}_{2} \mathrm{O}_{2}$. Symbols are experimental data derived from panel (b) and line is linear regression. 


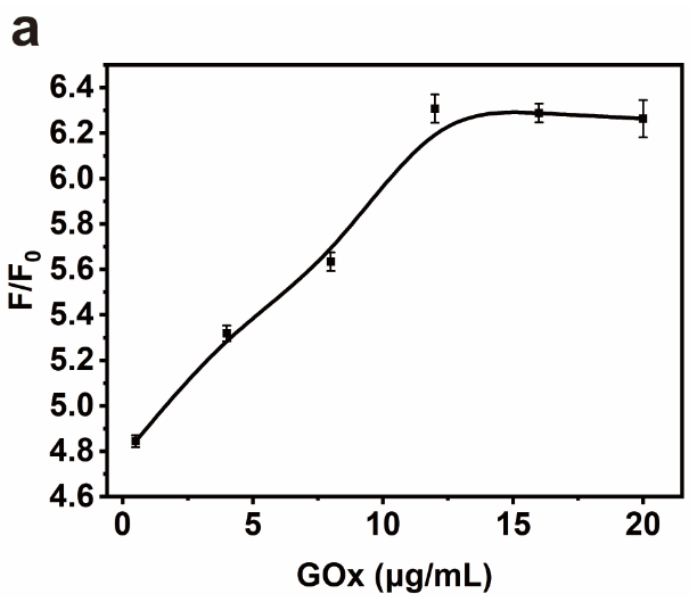

b

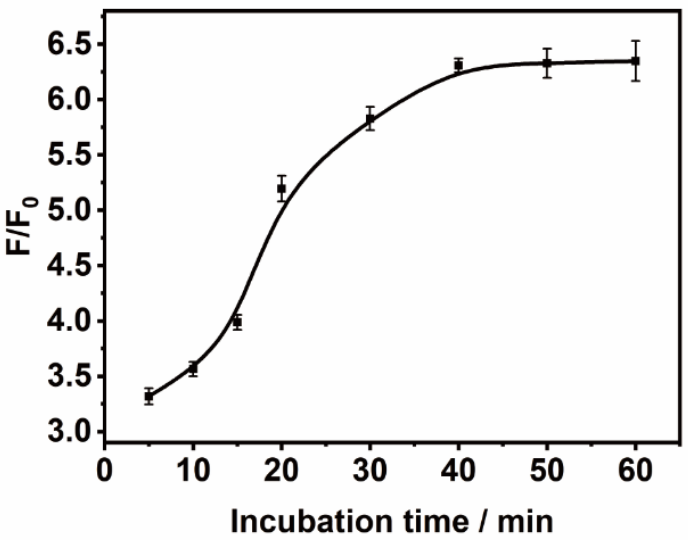

Figure S9. Dependence of the fluorescence response efficiency on GOx concentration (a) and incubation time (b).

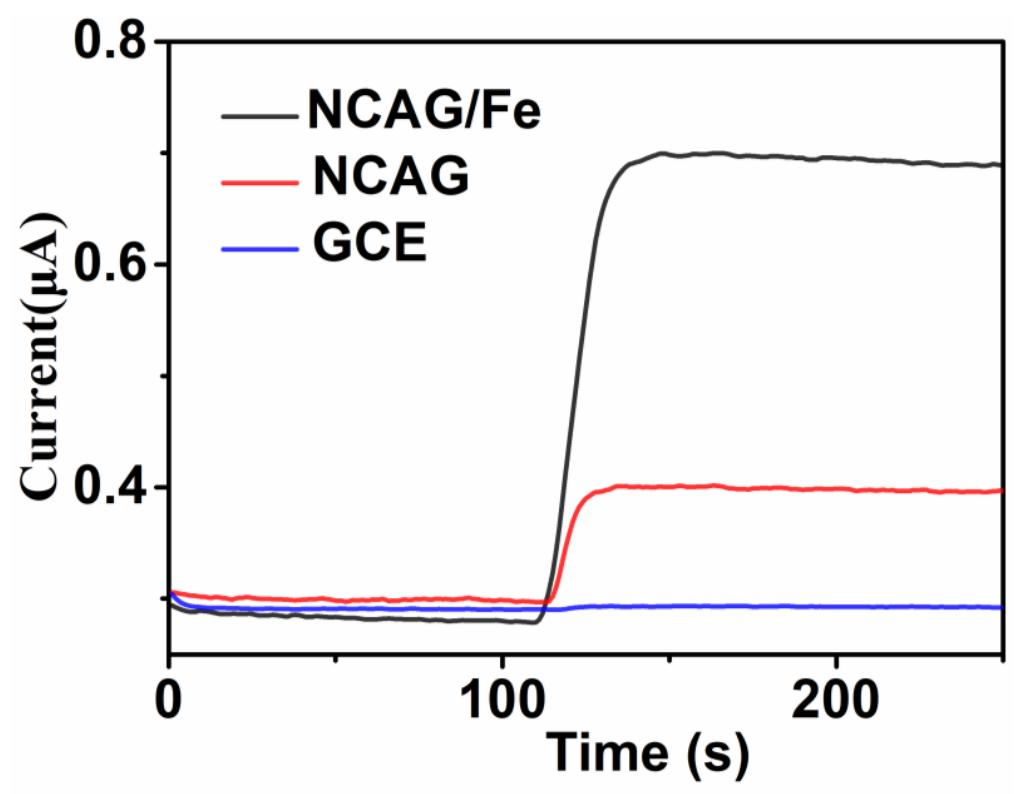

Figure S10. Chronoamperometric profiles of different modified electrodes at the applied potential of $+0.35 \mathrm{~V}$ toward successive additions of $100 \mu \mathrm{M}$ glucose in $0.1 \mathrm{M} \mathrm{NaOH}$. 
a

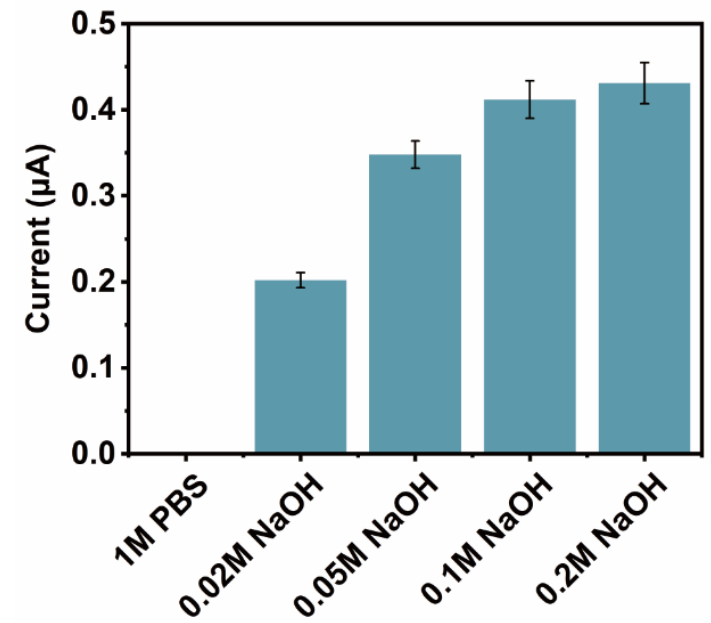

b

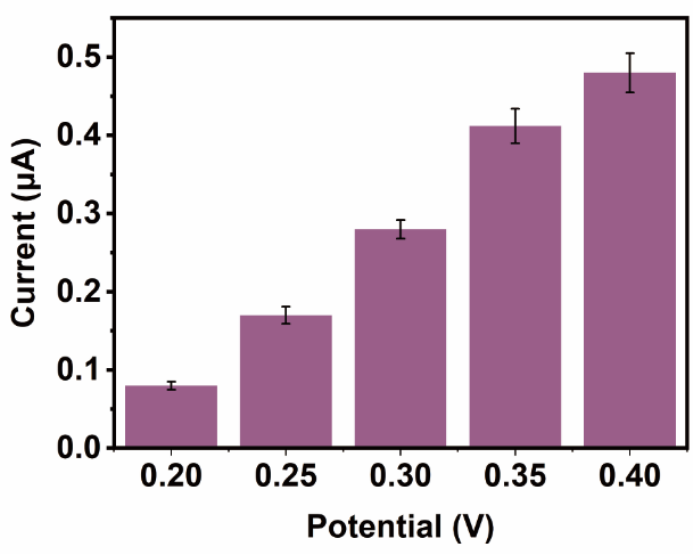

Figure S11 (a) Amperometric curves of NCAG/Fe in PBS or $\mathrm{NaOH}$ solution at different concentrations containing $100 \mu \mathrm{M}$ glucose at $0.35 \mathrm{~V}$ potentials. (b) Amperometric curves of $\mathrm{NCAG} / \mathrm{Fe}$ in $0.1 \mathrm{M} \mathrm{NaOH}$ solution containing $100 \mu \mathrm{M}$ glucose at different applied potentials.

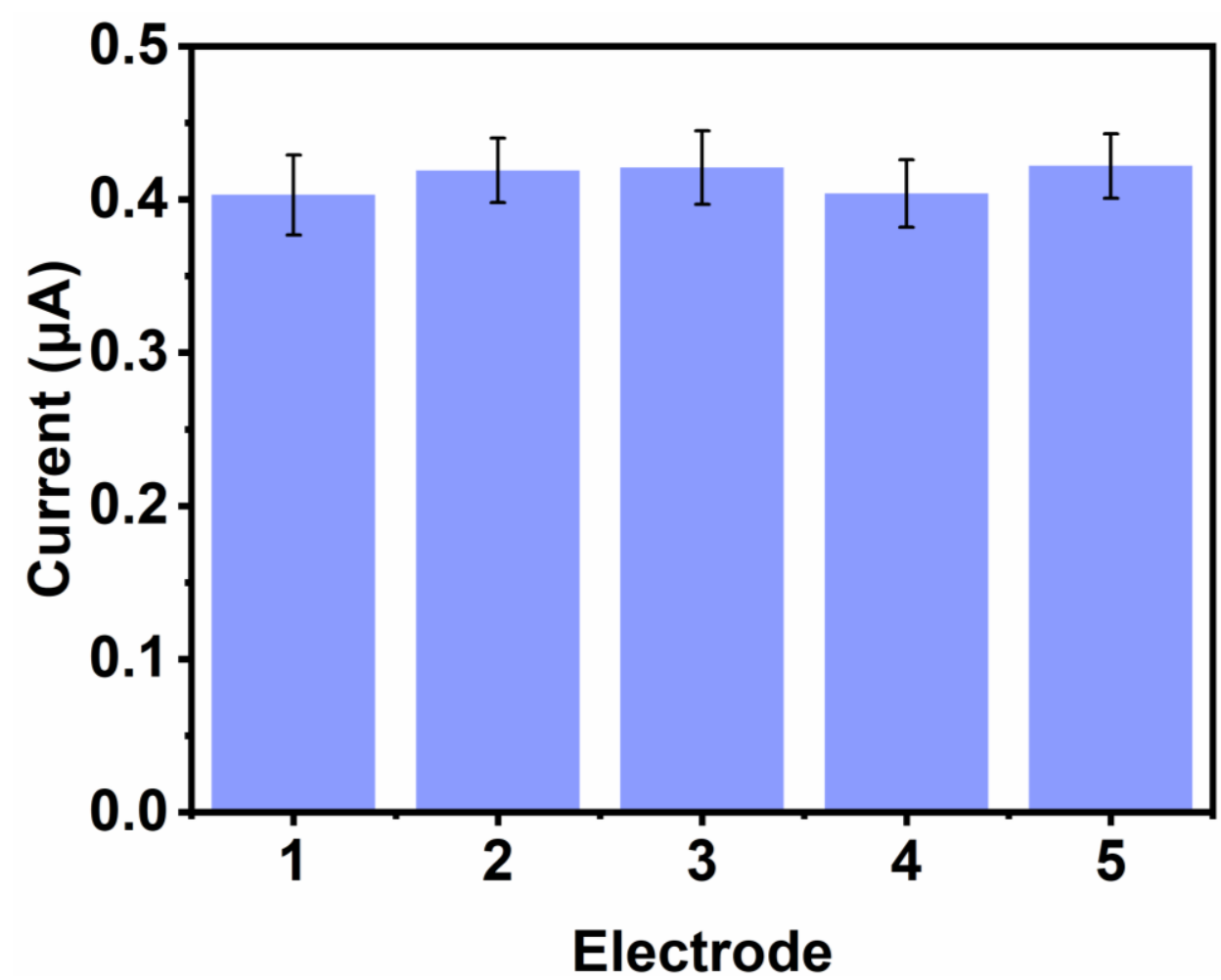

Figure S12 Current increments observed in amperometric measurements with five NCAG/Fe-modified electrodes at $+0.35 \mathrm{~V}$ with $100 \mathrm{mM}$ glucose in $0.1 \mathrm{M} \mathrm{NaOH}$. 
Table S1. Elemental composition of NCAG/Fe from XPS measurements

\begin{tabular}{ccc}
\hline Elements & Content (at\%) & Content (wt\%) \\
\hline $\mathbf{C}$ & 90.27 & 87.35 \\
$\mathbf{O}$ & 5.98 & 7.72 \\
$\mathbf{N}$ & 3.53 & 3.99 \\
$\mathrm{Fe}$ & 0.21 & 0.95 (0.70 from ICP-OES) \\
\hline
\end{tabular}

Table S2. Contents (at\%) of different $\mathbf{N}$ species from XPS measurements

\begin{tabular}{|c|c|c|c|c|c|}
\hline Species & $\begin{array}{c}\text { pyridinic N } \\
(398.2 \mathrm{eV})\end{array}$ & $\begin{array}{c}\text { Metal-N } \\
(398.8 \mathrm{eV})\end{array}$ & $\begin{array}{l}\text { Pyrrolic N } \\
(399.8 \mathrm{eV})\end{array}$ & $\begin{array}{c}\text { Graphitic N } \\
(400.9 \mathrm{eV})\end{array}$ & $\begin{array}{c}\text { Oxide N } \\
(402.5 \mathrm{eV})\end{array}$ \\
\hline $\begin{array}{l}\text { Content } \\
\text { ratio of } \mathrm{M}-\mathrm{N} \\
\text { to } \mathrm{Fe}\end{array}$ & 0.55 at $\%$ & $\begin{array}{c}0.83 \text { at } \% \\
3.95\end{array}$ & 0.11 at $\%$ & 1.85 at $\%$ & 0.18 at $\%$ \\
\hline
\end{tabular}

Table S3. Fitting results of the EXAFS data for NCAG/Fe

\begin{tabular}{cccccc}
\hline Sample & Shell & $\begin{array}{c}\text { Coordination } \\
\text { number }\end{array}$ & $\mathbf{R}(\mathbf{A})$ & R-factor & $\boldsymbol{\sigma}^{2}$ \\
\hline NCAG/Fe & Fe-N & 4.0 & 1.972 & 0.0043 & 0.0047 \\
\hline
\end{tabular}

Table S4. Comparison of the kinetic parameters of NCAG/Fe and HRP

\begin{tabular}{lccc}
\hline Catalyst & Substrate & $\mathrm{K}_{\mathbf{m}}(\mathbf{m M})$ & $\mathbf{V}_{\max }\left(\mathbf{1 0}^{-8} \mathbf{M ~ s}^{-1}\right)$ \\
\hline $\mathbf{N C A G / F e}$ & $\mathrm{OPD}$ & 0.19 & 5.15 \\
$\mathbf{N C A G / F e}$ & $\mathrm{H}_{2} \mathrm{O}_{2}$ & 0.23 & 28.53 \\
$\mathrm{HRP}^{1}$ & $\mathrm{OPD}$ & 0.59 & 4.65 \\
$\mathrm{HRP}^{1}$ & $\mathrm{H}_{2} \mathrm{O}_{2}$ & 0.34 & 9.48 \\
\hline
\end{tabular}

Table S5. Comparison of glucose sensing performance with relevant results reported recently in the literature

\begin{tabular}{|c|c|c|c|c|}
\hline Materials & Method & Linear Range $(\mu \mathrm{M})$ & LOD $(\mu \mathrm{M})$ & Ref. \\
\hline Graphene quantum dots & fluorescence & $100-10000$ & 30 & 2 \\
\hline $\mathrm{MnO}_{2}$-nanosheet & fluorescence & $0-250$ & 3.7 & 3 \\
\hline SiNPs & fluorescence & $10-7000$ & 3.5 & 4 \\
\hline $\mathrm{V}_{2} \mathrm{O}_{5}$ Nanozymes & colorimetric & $10-2000$ & 10.0 & 5 \\
\hline $\mathrm{CoPW}_{11} \mathrm{O}_{39}$ & colorimetric & $33-500$ & 23.4 & 6 \\
\hline $\mathrm{Fe}_{3} \mathrm{O}_{4} @ \mathrm{SiO}_{2} @ \mathrm{Au} \mathrm{MNPs}$ & colorimetric & $5-350$ & 3.0 & 7 \\
\hline Asp-modified CuS & colorimetric & $25-600$ & 4.9 & 8 \\
\hline $\mathrm{Fe@Pt/C}$ & electrochemistry & $1000-16000$ & 300 & 9 \\
\hline Pd-Au bimetallic cluster & electrochemistry & $100-30000$ & 50 & 10 \\
\hline \multirow{2}{*}{ NCAG/Fe } & fluorescence & $20-1000$ & 3.1 & \multirow{2}{*}{ This work } \\
\hline & electrochemistry & $2-2000$ & 0.5 & \\
\hline
\end{tabular}




\section{References}

1. Zhu, D.; Zhuo, S.; Zhu, C.; Zhang, P.; Shen, W., Synthesis of catalytically active peroxidase-like Fe-doped carbon dots and application in ratiometric fluorescence detection of hydrogen peroxide and glucose. Analytical Methods 2019, 11 (20), 2663-2668.

2. Zhang, L.; Zhang, Z.-Y.; Liang, R.-P.; Li, Y.-H.; Qiu, J.-D., Boron-Doped Graphene Quantum Dots for Selective Glucose Sensing Based on the "Abnormal" Aggregation-Induced Photoluminescence Enhancement. Analytical Chemistry 2014, 86 (9), 4423-4430.

3. Yuan, J.; Cen, Y.; Kong, X.-J.; Wu, S.; Liu, C.-L.; Yu, R.-Q.; Chu, X., MnO2-Nanosheet-Modified Upconversion Nanosystem for Sensitive Turn-On Fluorescence Detection of $\mathrm{H} 2 \mathrm{O} 2$ and Glucose in Blood. ACS Applied Materials \& Interfaces 2015, 7 (19), 10548-10555.

4. Ding, L.; Gong, Z.; Yan, M.; Yu, J.; Song, X., Determination of glucose by using fluorescent silicon nanoparticles and an inner filter caused by peroxidase-induced oxidation of o-phenylenediamine by hydrogen peroxide. Microchimica Acta 2017, 184 (11), 4531-4536.

5. Sun, J.; Li, C.; Qi, Y.; Guo, S.; Liang, X., Optimizing Colorimetric Assay Based on $\mathrm{V}_{2} \mathrm{O}_{5}$ Nanozymes for Sensitive Detection of $\mathrm{H}_{2} \mathrm{O}_{2}$ and Glucose. Sensors (Basel, Switzerland) 2016, 16 (4), 584.

6. He, Y.; Li, X.; Xu, X.; Pan, J.; Niu, X., A cobalt-based polyoxometalate nanozyme with high peroxidase-mimicking activity at neutral $\mathrm{pH}$ for one-pot colorimetric analysis of glucose. Journal of Materials Chemistry B 2018, 6 (36), 5750-5755.

7. Luo, S.; Liu, Y.; Rao, H.; Wang, Y.; Wang, X., Fluorescence and magnetic nanocomposite Fe3O4@SiO2@Au MNPs as peroxidase mimetics for glucose detection. Analytical Biochemistry 2017, 538, 26-33.

8. Niu, X.; Xu, X.; Li, X.; Pan, J.; Qiu, F.; Zhao, H.; Lan, M., Surface charge engineering of nanosized CuS via acidic amino acid modification enables high peroxidase-mimicking activity at neutral $\mathrm{pH}$ for one-pot detection of glucose. Chemical Communications 2018, 54 (95), 13443-13446.

9. Mei, H.; Wu, W.; Yu, B.; Wu, H.; Wang, S.; Xia, Q., Nonenzymatic electrochemical sensor based on Fe@Pt core-shell nanoparticles for hydrogen peroxide, glucose and formaldehyde. Sensors and Actuators B: Chemical 2016, 223, 68-75.

10. Shen, C.; Su, J.; Li, X.; Luo, J.; Yang, M., Electrochemical sensing platform based on Pd-Au bimetallic cluster for non-enzymatic detection of glucose. Sensors and Actuators B: Chemical 2015, 209, 695-700. 